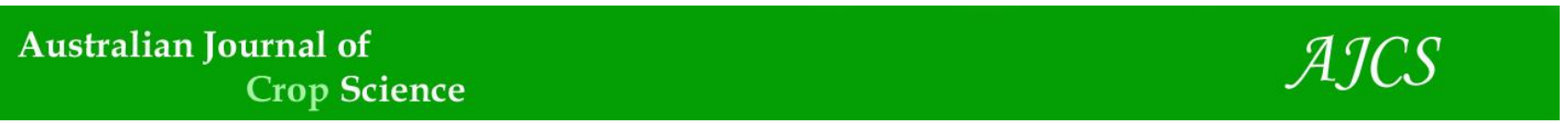

AJCS 14(08):1342-1347 (2020)

ISSN:1835-2707

doi: 10.21475/ajcs.20.14.08.p2632

\title{
Post-emergence nicosulfuron application enhanced leaf-stem ratio in maize- intercropped with Urochloa species after shading and sunlight re-exposure
}

\author{
Lucas F. N. Souza ${ }^{1}$, Silas M. Oliveira ${ }^{1}$, Rodrigo E. M. Almeida ${ }^{2^{*}}$, Clovis P. Junior ${ }^{1}$, João L. C. Baptistella ${ }^{1}$, \\ José L. Favarin ${ }^{1}$
}

${ }^{1}$ University of São Paulo, Department of Crop Science, Piracicaba, Brazil
${ }^{2}$ Embrapa Pesca e Aquicultura, Palmas, Brazil

*Corresponding author: rodrigo.almeida@embrapa.br

\section{Abstract}

Low rates of nicosulfuron used in post-emergence provide an advantage to maize during the coexistence of the crops, when maize is intercropped with Urochloa grasses. Nonetheless, the effect of this practice on the morphology of these grasses is not known, neither how it affects forage growth after the coexistence period nor when the grass is re-exposed to full sunlight. The aim of this study was to determine biomass and leaf-stem ratio of Urochloa hybrid cv. Mulatto II (CIAT 36087), Urochloa brizantha (Hochst. ex A. Rich.) and Urochloa ruziziensis (Germ. \& Evrard) after the development in a shade simulated environment promoted by maize in intercrop systems. The treatments consisted of three brachiaria species with two herbicides managements. Evaluations occurred at 0,30 and 60 days after the sunlight re-exposure (DASR). Nicosulfuron application and Urochloa species did not affect biomass yield. However, herbicide increased leaf-stem ratio of the species between $25 \%$ at 0 DARS to $62 \%$ at 30 DARS on old tillers (tillers that grew under shade). The biomass yield, as well the leaf-stem ratio of the new tillers was not affected. Among the species, the greater ratio of leaves in the plant biomass was recorded for Urochloa brizantha (Hochst. ex A. Rich.) and Urochloa hybrid cv. Mulatto II (CIAT 36087). Nicosulfuron use in post-emergence enhanced the leaf-stem ratio of Urochloa grasses after sunlight reexposure and a reliable alternative to improve forage quality in intercrop systems.

Keywords: Crop-livestock systems; Forage quality; Intercrop; Low rate Herbicides.

Abbreviations: DAS_days after sowing, DASR_days after sunlight re-exposure, ICLS_integrated crop-livestock system, New tillers_tillers that grew under full sunlight, Old tillers_tillers that grew under shade, New tillers_tillers that grew under sunlight.

The intercropping of maize with perennial tropical forages provides an effective mean of deploying Integrated CropLivestock System (ICLS) in tropical agriculture. In this intercrop, the forage and maize are sown at the same time, coexisting through all maize cycle. After harvesting the maize, forage can be used for grazing. If well-managed, this intercrop results in the same yield as sole maize production and an additional 2 to $5 \mathrm{Mg} \mathrm{ha}^{-1}$ of Urochloa spp. biomass in dry season, the most used forage genus for this purpose (Pariz et al., 2011; Almeida et al., 2018).

During coexistence period, the forage can compete with maize for resources, such as light, water, nutrients and space. Ensuring lower competition for maize growth resources is a key factor for the success of the intercrop. For this matter, some measures have been used, such as spraying low herbicides rates on the forage. Using lower herbicides rates than the recommended aims at hindering forage growth during coexistence period (Jakelaitis et al., 2006). The most used herbicide to suppress the forage growth in ICLS is nicosulfuron (Almeida et al., 2018; Oliveira et al., 2018; Pariz et al., 2017). Despite the fact that the recommended rate of nicosulfuron is lethal to Urochloa spp., the low rate may cause suppression on forage, decreasing the competition between the two species (Anésio et al., 2017). It provides maize competitive advantage over Urochloa spp, resulting in reduced light availability to the forage. As maize intercepts more sunlight, it grows faster and uses resources quicker. By doing so, it becomes the dominant species of the intercrop and Urochloa., the subordinate one.

Urochloa remains shaded during maize cycle and most of the times it results in etiolation process of the forage (Paciullo et al., 2011). Etiolation alters the chemical composition and morphology of the forage, affecting fibrous accumulation on stem (Pariz et al., 2016). Etiolation effects on Urochloa could be reduced using post-emergence herbicides during the period of shadow, which would be desirable because etiolation enhances the lignin content in the plant tissues, decreasing its digestion by ruminants (Gallego-Giraldo et al., 2016). Overall, stretched out plants have less leaf/stem ratio and enhanced lignin content, limiting factors for selection and forage intake by grazing animals (Glienke et al., 2016). However, the effect of the herbicide applied postemergence on intercropped grasses morphology is 
unknown, or its effects after the end of coexistence period of the two species, when the forage is used for animal grazing.

Supporting organs, such as roots and stems, have a higher lignin contents in xylem and sclerenchyma tissues (Valente et al., 2016) and as a result, there are several studies correlating the nutritive quality and lignin content of the forages through the relation between leaves and stems (Brito et al., 2004; Dumont et al., 2015). On the other hand, spraying herbicides could reduce forage yield, which would affect the carrying capacity of the ILCS area. This biomass reduction is unwanted, in view of the fact that Urochloa is an important source of forage in winter dry season, as in the Brazilian Cerrado, which has average rainfall around $60 \mathrm{~mm}$ $\mathrm{ha}^{-1}$ during these seasons (Oliveira et al., 2015).

The objective of this study was to investigate the effect of low nicosulfuron rate on morphology of the genus Urochloa spp. sprayed post-emergence at shadow conditions, similar to the conditions of maize and forage intercropping. Also, we investigated three species of Urochloa, since significant differences among these species had been reported, when shaded by maize in intercropping (Paciullo et al., 2011; Maia et al., 2014; Simão et al., 2018).

\section{Results and Discussion}

\section{Biomass}

The spraying of low herbicide rate and the Urochloa species did not affect the biomass of the tillers growing under shadow conditions, named old tillers (Table 1). A positive correlation between biomass and sampling data was recorded, from $32.5 \mathrm{~g}$ pot-1 to $62.5 \mathrm{~g} \mathrm{pot}^{-1}$. Tillers that grew under full sunlight (new tillers) - after the removal of the shading net - were also not affected by the low herbicide rate spray or Urochloa species. The new tillers biomass average was $21.1 \mathrm{~g} \mathrm{pot}^{-1}$. There was no difference in the total biomass (new + old) among the species. Total biomass increased throughout time sampling, 54, 67.7 and $84.4 \mathrm{~g}$ pot ${ }^{1}$ for 0,30 and 60 DARS, respectively (Table 1).

Biomass yield of Urochloa growing under shadow conditions was not affected by low herbicide rate. Alvarenga et al. (2011) also recorded no differences in Urochloa brizantha biomass between control (no herbicide) and plants that received low nicosulfuron rates at maize harvesting. The authors also concluded that low nicosulfuron rates were an important management to avoid interspecific competition in the intercrop.

\section{Leaf stem ratio}

The leaf stem ratio of the old tillers presented significant interactions for sampling date vs species and sampling date vs low herbicides rate (Table 2 ). U. brizantha and U. mullato II reached the greater leaf proportion resulting in larger leafstem ratio (Figure $1 \mathrm{~A}$ ). Throughout the sampling dates, the leaf-stem ratio decreased in all Urochloa species (Figure 1A). Low herbicide rate increases leaf-stem ratio for all species at 0 and 30 DARS in comparison to the control with no spraying (Figure 1B). For new tillers, species and herbicide spray did not affect the leaf stem ratio (Table 1). Overall, the leaf-stem ratio among new tillers was 1.32 . Among the species, $U$. brizantha and $U$. mullato II obtained the greater total leafstem ratio through the sampling date, 1.25 and 1.27 respectively (Table 1). Significant interaction of sampling date and graminicide were recorded to total leaf-stem ratio. Low rate herbicide spraying increased leaf-stem ratio for all Urochloa species at 0 and 30 DARS collection period (Figure 1C).

Management and environmental conditions affected the leaf-stem ratio for Urochloa spp. In monoculture, the leafstem ratio ranged from 0.71 to 2.5 (Fagundes et al., 2006; da Silveira et al., 2016) and from 0.4 to 2.0, when growing in intercrop arrangement (Portes et al., 2000; Martuscello et al., 2017). Our results are in accordance with what was previously reported in the literature, but when low herbicide rates were used, significant differences among species and collected periods were recorded (Figure $1 \mathrm{~B}$ and C). Herbicides from the sulfonylurea group, such as nicosulfuron, are absorbed and transported to apical points (Durner et al., 2008; Shergill et al., 2018), to restrict amino acids production. Low nicosulfuron rate did not kill Urochloa plants. However, they certainly impaired the stems elongation and redirected plant growing to leaves, enhancing leaf-stem ratio. According to Jakelaitis et al. (2006) even doses ten times lower ( $2 \mathrm{~g}$ a.i. $\mathrm{ha}^{-1}$ ) than used at the present work can promote the biomass reduction in Urochloa plants, showing that the hormesis effect can be probably discarded once even lower doses can be toxic to this gender. After sunlight re-exposure at 150 DAS, Urochloa growth was enhanced and the leaf-stem ratio of the plants that received low herbicide rates reached similar values of the plants with no herbicide spraying. Portes et al. (2000) suggested that there is a rearrangement of the morphology of the intercropped Urochloa after the re-exposure to sunlight. The authors reported no differences between intercropped and monoculture Urochloa brizantha in biomass, number of tillers and leaf area index at 70 DASR, when oldest leaves were re-exposed to full sunlight. Almeida et al. (2017) evaluated methods of establishment of the intercrop between maize and forage with cultivars of Panicum spp. and concluded that the late implantation of the forage also increased the leaf-stem ratio. In this study, forage stress caused high levels of shade, instead of herbicide application, but biomass yield was lower. In the present study, the simulation was done for simultaneous planting of maize and forage and the application of low herbicide rate increased the proportion of leaves with no biomass yield impairment. Among the Urochloa species, $U$. brizantha and $U$. mullato I/ presented a greater proportion of leaves comparing to $U$. ruziziensis. Investigating six Urochloa species intercropped with maize, Maia et al. (2014) reported similar results for leaf-stem ratio. After the maize grain harvest, values of cellulose, hemicellulose, and $\mathrm{N}$ lignified were lower for U. brizantha cultivars. For the same parameters, Pariz et al. (2010) reported similar variation among Urochloa species due to shadow effects caused by intercrop arrangement. These results are consistent with findings reported herein and show that Urochloa species is an important factor to provide greater forage quality under shadow conditions. Through our results, it is possible to affirm that in the short term, the low herbicide rates in postemergence in the intercropping of maize with Urochloa will not affect the biomass production but will improve the leafstem ratio. This information is useful for obtaining high pasture quality after maize harvesting, or for maize silage 
Table 1. Combined analysis of variance among date sampling, species and low herbicide rate use for biomass.

\begin{tabular}{|c|c|c|c|c|c|c|c|}
\hline DASR $^{1}$ & Urochloa spp. & $\begin{array}{l}\text { Biomass } \\
\text { "Old" } \\
\text { Without } \\
\text { herbicide } \\
\text { g. pot }{ }^{-1}\end{array}$ & Nicosulfuron & $\begin{array}{l}\text { Biomass } \\
\text { "New" } \\
\text { Without } \\
\text { herbicide } \\
\text { g.pot }{ }^{-1}\end{array}$ & Nicosulfuron & $\begin{array}{l}\text { Biomass } \\
\text { Total } \\
\text { Without } \\
\text { herbicide } \\
\text { g.pot }{ }^{-1}\end{array}$ & Nicosulfuron \\
\hline & U. brizantha & 36.4 & 30.7 & 21.5 & 20.6 & 57.9 & 51.2 \\
\hline \multirow[t]{2}{*}{0} & U. mullato II & 31.8 & 27.2 & 20.7 & 21.8 & 52.5 & 49.0 \\
\hline & U. ruziziensis & 34.7 & 34.1 & 21.2 & 23.7 & 55.8 & 57.7 \\
\hline \multicolumn{2}{|c|}{ Mean 0 DASR } & $32.5 \mathrm{C}$ & & $21.6 \mathrm{~A}$ & & $54.0 \mathrm{C}$ & \\
\hline & U. brizantha & 48.2 & 35.0 & 19.5 & 19.3 & 67.7 & 54.4 \\
\hline \multirow[t]{2}{*}{30} & U. mullato II & 48.2 & 49.3 & 19.5 & 19.3 & 67.7 & 68.7 \\
\hline & U. ruziziensis & 54.0 & 53.1 & 19.9 & 19.0 & 73.9 & 72.2 \\
\hline \multicolumn{2}{|c|}{ Mean 30 DASR } & $48.0 \mathrm{~B}$ & & $19.4 \mathrm{~B}$ & & $67.4 \mathrm{~B}$ & \\
\hline & U. brizantha & 87.2 & 85.4 & 24.0 & 23.7 & 87.2 & 85.4 \\
\hline \multirow[t]{2}{*}{60} & U. mullato II & 93.2 & 86.1 & 20.9 & 22.7 & 93.2 & 86.1 \\
\hline & U. ruziziensis & 79.5 & 77.4 & 20.5 & 21.7 & 79.5 & 77.4 \\
\hline \multicolumn{2}{|c|}{ Mean 60 DASR } & $62.5 \mathrm{~A}$ & & $22.3 \mathrm{~A}$ & & $84.4 \mathrm{~A}$ & \\
\hline \multicolumn{8}{|c|}{${ }^{1}$ DASR = days after sunlight re-exposure; ANOVA $(\mathrm{Pr}>\mathrm{F})$} \\
\hline \multicolumn{2}{|c|}{ Colleted Period (C) } & $* * *$ & & ns & & $* * *$ & \\
\hline \multicolumn{2}{|r|}{ Urochloa spp. (U) } & ns & & ns & & ns & \\
\hline \multicolumn{2}{|r|}{ Graminicide (G) } & ns & & ns & & ns & \\
\hline \multicolumn{2}{|r|}{$\mathrm{C}^{*} \mathrm{U}$} & ns & & ns & & ns & \\
\hline \multicolumn{2}{|r|}{$C^{*} \mathrm{G}$} & ns & & ns & & ns & \\
\hline \multicolumn{2}{|r|}{$\mathrm{U} * \mathrm{G}$} & ns & & ns & & ns & \\
\hline \multicolumn{2}{|r|}{$C * U * G$} & ns & & ns & & ns & \\
\hline \multicolumn{2}{|r|}{ CV \% } & 25.3 & & 12.3 & & 19.1 & \\
\hline
\end{tabular}

A $\bullet U$. brizantha $\triangle$ U. mullato $\boldsymbol{\square} U$. ruziziensis

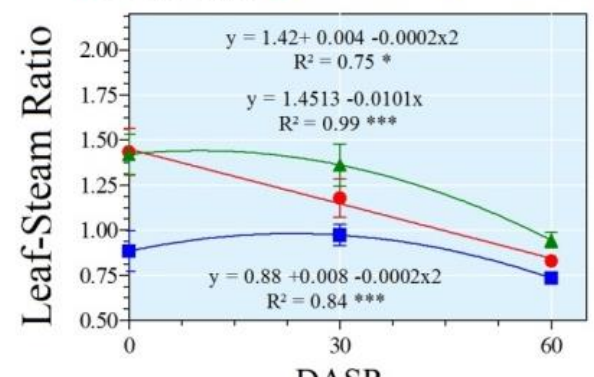

B $\bullet$ Without graminicide $\Delta$ With graminicide

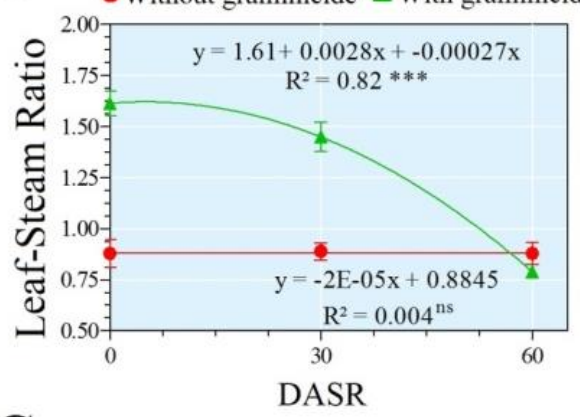

C Without graminicide $\Delta$ With graminicide

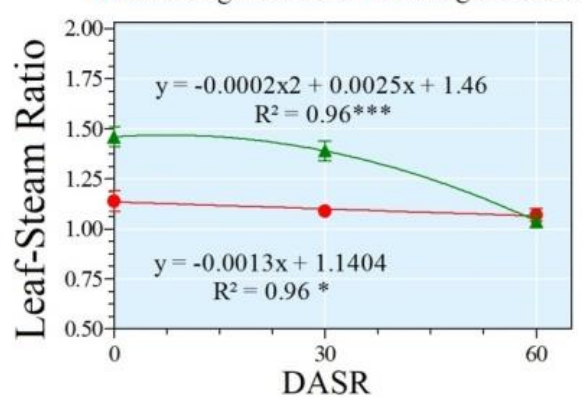

Fig 1. Urochloa spp. leaf-stem ratio of the old tillers; (A) low rate herbicide effects on the leaf-stem ratio of the old tillers (B) and total tillers (C) (mean of the species). Vertical bars indicate standard error. 
Table 2. Combined analysis of variance among date sampling, species and herbicide use for leaf-stem ratio.

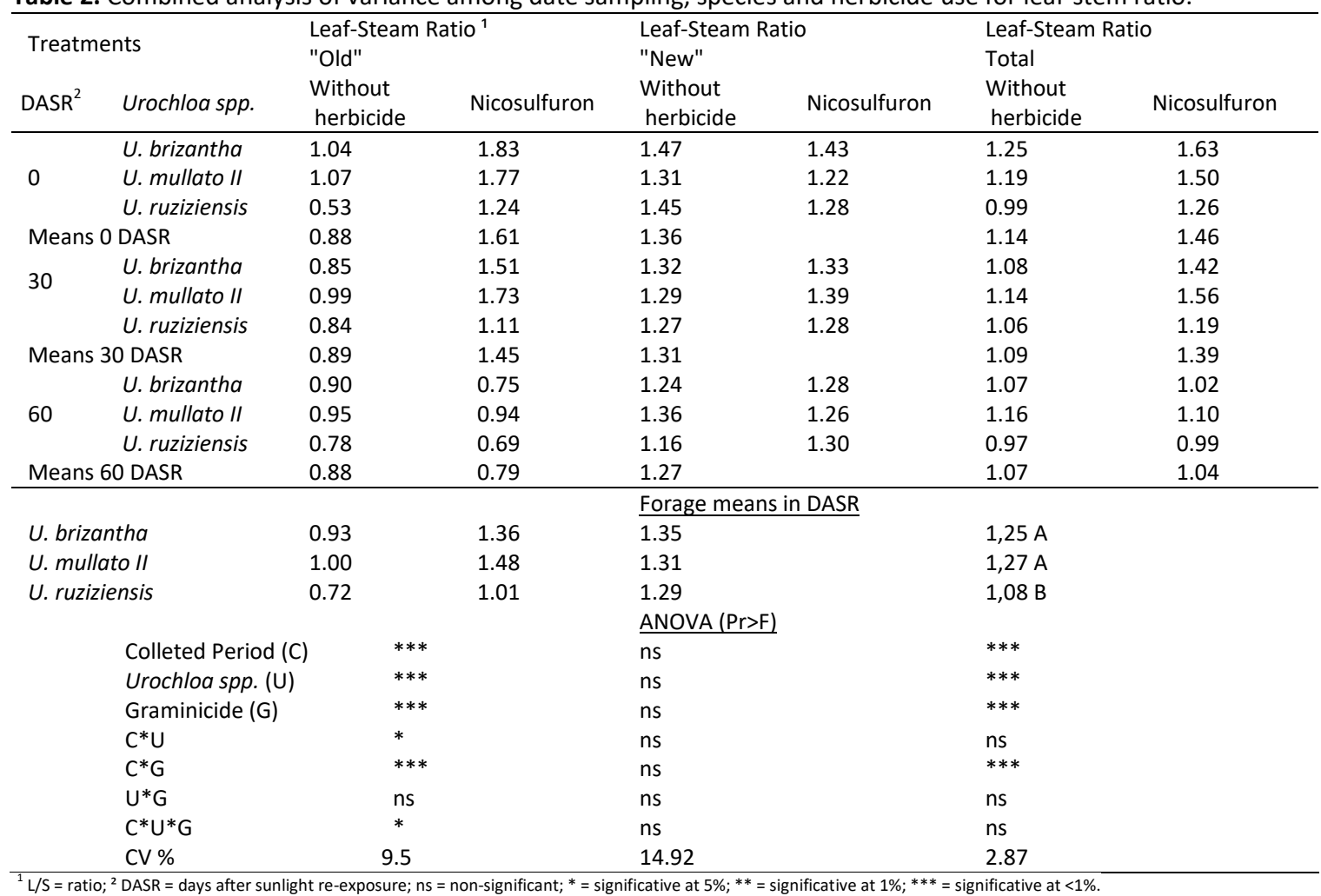

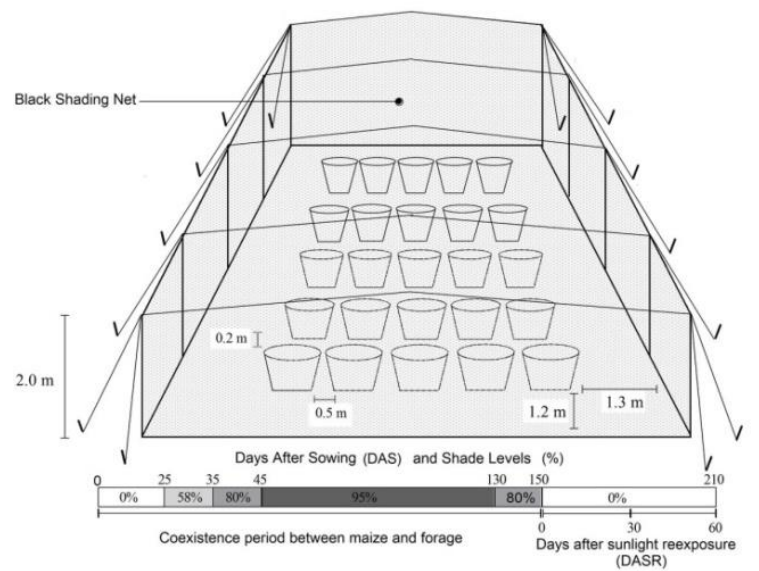

Fig 2. The greenhouse structure to simulate shade levels. All treatments received equal shade levels and at the same time.

and forage production (Freitas et al., 2005; Mendonça et al., 2014).

\section{Materials and Methods}

\section{Plant materials}

In this study, three Urochloa species, commonly cultivated as forage in Brazilian fields, were utilized. They were $U$. brizantha cv. Marandu, U. ruziziensis, and a Urochloa hybrid between $U$. brizantha, $U$. decumbens and $U$. ruziziensis called Urochloa spp. hybrid cv. Mulatto II (CIAT 36087).

\section{Experimental conditions}

A greenhouse experiment was carried out from September 2015 to May 2016 in the Crop Science Department of
University of São Paulo in Piracicaba, Brazil. Throughout the experimental period, the average air temperature ranged

from $23.6^{\circ}$ to $27^{\circ} \mathrm{C}$. Irrigation was managed to ensure $70 \%$ of the soil field capacity and to avoid water stress.

The experimental design was of complete randomized blocks with 18 treatments in factorial design $3 \times 3 \times 2$ and five repetitions. The treatments were composed by three Urochloa sampling dates: 0 days after sunlight re-exposure (DASR), 30 DARS and 60 DASR; (2) three species of the genus Urochloa spp.: Urochloa spp. hybrid cV. Mulatto II (CIAT 36087), described as U. mulatto II; Urochloa brizantha cv. Marandu; and Urochloa ruziziensis; (3) with and without the application of herbicide nicosulfuron sub dose. All treatments aimed to simulate the shading condition that brachiaria species develop, when intercropped with maize in field. 


\section{Establishment of the treatments}

The Urochloa species were sown in pots of $25 \mathrm{~kg}$ filled with typical Dystrophic Red Latosol (Oxisols) and spaced $0.5 \mathrm{~m}$ to each other, similar to the maize grass intercrop. The base saturation of the soil was adjusted to $70 \%$ with limestone application 120 days prior to the implementation of the experiment. General Urochloa fertility management was adjusted according to the recommendations of Raij et al. (1997).

The herbicide nicosulfuron (Sanson 40SC ${ }^{\circledR}, 40 \mathrm{~g}$ ai $\mathrm{L}^{-1}$, ISK Biosciences Brasil, 448 Av. Fábio Ferraz Bicudo, Indaiatuba, São Paulo, Brasil) was applied at a rate of $25 \mathrm{~g}$ a.i. ha ${ }^{-1}, 20$ days after sowing, when all species started tillering. Previous studies report similar rate and time to Urochloa intercropped with maize on field (Garcia et al., 2013; Pariz et al., 2016). The application of the herbicide was performed with a backpack $\mathrm{CO}_{2}$ pressurized sprayer that applied a constant pressure of $196 \mathrm{MPa}$ and that was fitted with an application wand equipped with a 2 meters long bar and four Teejet XR 110.2 flat spray tip spaced 0.5 meter to each other and calibrated for a spray volume of $200 \mathrm{~L} \mathrm{ha}^{-1}$. The application was performed late in the late afternoon, for there was mild temperature and higher relative air humidity during the time of application, to increase its efficacy (Ramos et al., 2010). In order to simulate the light availability to Urochloa during intercropping, all pots were gradually shaded during the experiment according to shade levels and respective dates previously obtained in a maize plantation with 150-day cycle (unpublished data). Therefore, shading levels were $58 \%, 80 \%, 95 \%$ and $80 \%$ at $25,35,45$, and 130 days after sowing (DAS), respectively. At 150 DAS, the plants were re-exposed to full sunlight, simulating postharvest condition in the maize-Urochloa intercrop.

Shading levels were adjusted with a luximeter model LD 200. Full luminosity (100\%) was measured at full sun, at 12:00 hours and with a clear sky. Thereafter, shadow levels were adjusted overlapping black shading nets. Light level was measured at ten random points $0.5 \mathrm{~m}$ above the pots. Details are presented in Figure 2.

\section{Data collection}

At the end of the shading period, at 150 DAS, all the tillers were marked in each pot and named "old". The evaluations of the old tillers were performed at 0,30 and 60 DASR. All the tillers that emerged after the 150 DAS were called "new" and their evaluations were also performed. Total biomass and total leaf-stem ratio was obtained from new and old tillers.

Immediately after the samples harvest, a subsample was taken to determine the leaf-stem ratio. The leaf blade with the sheaths was considered as the leaf. The remaining material was named stem. The plant material collected from the pots was dried for $72 \mathrm{~h}$ in a forced-air oven at $60{ }^{\circ} \mathrm{C}$ to measure dry mass.

\section{Conclusion}

The application of low nicosulfuron rates and the different species of Urochloa spp. did not affect the forage biomass production under shading conditions. However, the leafstem ratio among the Urochloa species was increased by up to $100 \%$, when the herbicide was sprayed over forage leaves. The greater leaf-stem ratio was recorded for $U$. brizantha and U. mullato II. These results suggest that low nicosulfuron rates in post-emergence enhanced the forage quality and can be a useful tool for intercrop arrangements aiming for animal grazing post-harvest of maize.

\section{Acknowledgments}

This research received no specific grant from any funding agency, commercial or not-for-profit sectors. No conflicts of interest have been declared.

\section{References}

de Almeida REM, Favarin JL, Otto R, Franco HCJ, Reis AFB, Moreira LA, Trivelin PCO (2018) Nitrogen recovery efficiency for corn intercropped with palisade grass. Bragantia. 77:557-566.

de Almeida REM, Gomes CM, Lago BC, de Oliveira SM, Junior $C P$, Favarin JL (2017) Corn yield, forage production and quality affected by methods of intercropping corn and panicum maximum. Pesqui Agropecu Bras. 52:170-176.

Alvarenga RC, Gontijo Neto MM, Castro AADN, Coelho AM, Clemente EP (2011) Rendimento do consórcio milhobraquiária brizantha afetado pela localização do adubo e aplicação de aerbicida. Rev Bras Milho e Sorgo. 10:224234.

Anésio AHC, Santos MV, Silveira RR, Ferreira EA, Braz TGS, Tuffi Santos LD, Santos JB (2017) Herbicide selectivity to signal grass and congo grass. Planta Daninha. 35: e017157521.

Brito CJFA de, Rodella RA, Deschamps FC (2004) Anatomia quantitativa da folha e do colmo de Brachiaria brizantha (Hochst. ex A. Rich.) Stapf e B. humidicola (Rendle) Schweick. Rev Bras Zootec. 33:519-528.

Dumont B, Andueza D, Niderkorn V, Lüscher A, Porqueddu C, Picon-Cochard C (2015) A meta-analysis of climate change effects on forage quality in grasslands: specificities of mountain and mediterranean areas. Grass Forage Sci. 70:239-254.

Durner J, Gailus V, Boger P (2008) New aspects on inhibition of plant acetolactate synthase by chlorsulfuron and imazaquin. Plant Physiol. 95:1144-1149.

Fagundes JL, Fonseca DM da, Morais RV de, Mistura C, Vitor CMT, Gomide JA, Nascimento Junior D do, Santos MER, Lambertucci DM (2006) Avaliação das características estruturais do capim-braquiária em pastagens adubadas com nitrogênio nas quatro estações do ano. Rev Bras Zootec. 35:30-37.

Freitas FCL, Ferreira LR, Ferreira FA, Santos MV, Agnes EL, Cardoso AA, Jakelaitis A (2005) Implantation of pastures via consortium of Brachiaria brizantha with corn for silage under no-tillage system. Planta Daninha. 23:49-58.

Gallego-Giraldo L, Shadle G, Shen H, Barros-Rios J, Fresquet Corrales S, Wang H, Dixon RA (2016) Combining enhanced biomass density with reduced lignin level for improved forage quality. Plant Biotechnol J. 14:895-904.

Garcia CM de P, Andreotti M, Teixeira Filho MCM, Buzetti S, Celestrino T de S, Lopes KSM (2013) Desempenho agronômico da cultura do milho e espécies forrageiras em sistema de integração lavoura-pecuária no cerrado. Ciência Rural. 43:589-595.

Glienke CL, Rocha MG, Pötter L, Roso D, Montagner DB, Oliveira Neto RA, Glienke CL, Rocha MG, Pötter L, Roso D, Montagner DB, Oliveira Neto RA (2016) Canopy structure, ingestive behavior and displacement patterns of beef 
heifers grazing warm-season pastures. Arq Bras Med Veterinária e Zootec. 68:457-465.

Jakelaitis A, Alberto A, Ferreira A, Lopes L, Roberto L, Vivian $R$ (2006) Effects of herbicides on intercropped maize and Brachiaria brizantha weed control, growth and yield. Pesqui Agropecuária Trop. 36:53-60.

Maia GA, Aparecida K, Costa DP, Severiano C, Epifanio PS, Neto JF, Ribeiro MG (2014) Yield and chemical composition of brachiaria forage grasses in the offseason after corn harvest. Am J Plant Sci. 5:933-941.

Martuscello JA, Amorim PL, da Cunha D de NFV, Ferreira PS, Ribeiro4 LS, Souza MWM (2017) Morphogenesis and structure of signal grass in crop livestock integration system. Ciênc Anim Bras. 19:33-42.

Mendonça VZ de, Mello LMM de, Pereira FCBL, Silva JO da R, Yano ÉH (2014) Corn production for silage intercropped with forage in the farming-cattle breeding integration. Eng Agrícola. 34:738-745.

Oliveira PTS, Wendland E, Nearing MA, Scott RL, Rosolem R, da Rocha HR (2015) The water balance components of undisturbed tropical woodlands in the brazilian cerrado. Hydrol Earth Syst Sci. 19:2899-2910.

De Oliveira SM, De Almeida REM, Ciampitti IA, Junior CP, Lago BC, Trivelin PCO, Favarin JL (2018) Understanding N timing in corn yield and fertilizer $\mathrm{N}$ recovery: an insight from an isotopic labeled-N determination. PLoS One. 13:114.

Paciullo DSC, Fernandes PB, Gomide CADM, Castro CRT de, Sobrinho F de S, Carvalho CAB de (2011) The growth dynamics in Brachiaria species according to nitrogen dose and shade. Rev Bras Zootec. 40:270-276.

Pariz CM, Andreotti M, Azenha M V, Bergamaschine AF, de Mello LMM, Lima RC (2011) Corn grain yield and dry mass of brachiaria intercrops in the crop-livestock integration system .Cienc Rural. 41:875-882.

Pariz CM, Andreotti M, Azenha MV, Bergamaschine AF, Mano De Mello LM, Lima RC (2010) Dry mass and chemical composition of four brachiaria species sown in rows or spread, in intercrop with corn crop in no-tillage system. Acta Sci - Anim Sci. 32:147-154.
Pariz CM, Costa C, Crusciol CAC, Meirelles PRL, Castilhos AM, Andreotti M, Costa NR, Martello JM, Souza DM, Protes VM, Longhini VZ, Franzluebbers AJ (2017) Production, nutrient cycling and soil compaction to grazing of grass companion cropping with corn and soybean. Nutr Cycl Agroecosystems. 108:35-54.

Pariz CM, Costa C, Crusciol CAC, Meirelles PRL, Castilhos AM, Andreotti M, Costa NR, Martello JM, Souza DM, Sarto JRW, Franzluebbers AJ (2016) Production and soil responses to intercropping of forage grasses with corn and soybean silage. Agron J. 108:2541-2553.

Portes TDA, Carvalho SIC, Oliveira IP, Kluthcouski J (2000) Análise do crescimento de uma cultivar de braquiária em cultivo solteiro e consorciado com cereais. Pesqui Agropecuária Bras. 35:1349-1358.

Raij BV, Cantarella H, Quaggio JA, Furlani AMC (1997) Recomendaçoes de adubaçaoe calagem para o Estado de Sao PauloBoletim técnico, 100. Campinas: Instituto Agronômico \& Fundação IAC. $285 \mathrm{p}$

Shergill LS, Barlow BR, Bish MD, Bradley KW (2018) Investigations of 2,4-D and multiple herbicide resistance in a missouri waterhemp (Amaranthus tuberculatus) population. Weed Sci. 66:386-394.

da Silveira MCT, Júnior D do N, Rodrigues CS, Pena K da S, de Souza SJ, Barbero LM, Limão VA, Euclides VPB, da Silva SC (2016) Forage sward structure of mulato grass (Brachiaria hybrid ssp.) subjected to rotational stocking strategies. Aust J Crop Sci. 10:864-873.

Simão EDEP, Marques M, Neto G, Nolasco S, Neto DEO, Carlos J, Galvão C, Borghi E, Carvalho D, Vilela Á (2018) Grain and forage production in the function of luminous availability in integrated crop-livestock-forestry systems. Rev Bras Milho e Sorgo. 17:111-112.

Valente TNP, Lima E da S, Gomes ID, dos Santos WBR, Cesário AS, Santos SC (2016) Anatomical differences among forage with respect to nutrient availability for ruminants in the tropics: A review. African J Agric Res. 11:1585-1592. 